\title{
DOES AMBIENT TOBACCO SMOKE EXPOSURE INCREASE THE RISK OF PRETERM BIRTH? A NEW MULTIVARIATE EVIDENCE FROM SURAKARTA, INDONESIA
}

\author{
Harrys Bachtiar'1), Uki Retno Budihastuti2), Harsono Salimo3)
}

1)Masters Program in Public Health, Universitas Sebelas Maret

2)Department of Obstetrics and Gynecology, Dr. Moewardi Hospital, Surakarta

3)Department of Pediatrics, Dr. Moewardi Hospital, Surakarta

\begin{abstract}
Background: A handful of studies have reported a positive association between exposure to environmental tobacco smoke and an increased risk for preterm birth. However, such studies using data from Indonesian population are lacking. This study aimed to estimate the effect of ambient tobacco smoke exposure on the risk of preterm birth, after controlling for the effects of maternal age, parity, and maternal middle upper arm circumference (MUAC).

Subjects and Methods: This was a case control study conducted at Dr. Moewardi Hospital, Surakarta, Indonesia, using retrospective data in March 2018 and concurrent data in April and May 2018. A total sample of 200 newborn infants were selected for this study, comprising 50 preterm newborn infants and 150 term newborn infants. The dependent variable was prematurity. The independent variables included environmental tobacco smoke exposure during pregnancy, maternal age, parity, and maternal MUAC. Data were collected by a set of questionnaire. MUAC was measured by MUAC tape. The data were analyzed by multiple logistic regression model.

Results: Ambient tobacco smoke exposure increased the risk of preterm birth $(\mathrm{OR}=4.16 ; 95 \% \mathrm{CI}=1.51$ to $11.47 ; \mathrm{p}=0.006)$. This estimate has accounted for the effects of confounding factors, including maternal age $<20$ or $\geq 35$ years $(\mathrm{OR}=$ $4.84 ; 95 \% \mathrm{CI}=1.91$ to $12.22 ; \mathrm{p}=0.001)$, parity $\geq 4(\mathrm{OR}=5.89 ; 95 \% \mathrm{CI}=2.39$ to $14.47 ; \mathrm{p}<0.001)$, and $\mathrm{MUAC} \geq 23.5 \mathrm{~cm}(\mathrm{OR}=0.14 ; 95 \% \mathrm{CI}=0.05$ to 0.34 ; $\mathrm{p}<0.001)$. Nagelkerke $\mathrm{R}^{2}=56.9 \%$.

Conclusion: Ambient tobacco smoke exposure increases the risk of preterm birth, after controlling for the effect of maternal age, parity, and MUAC.
\end{abstract}

Keywords: tobacco smoke, maternal age, parity, MUAC, preterm birth

\section{Correspondence:}

Harrys Bachtiar. Masters Program on Public Health, Universitas Sebelas Maret. Jl. Ir. Sutami No. 36A, Surakarta 57126, Indonesia.

Email: harrysbachtiar@gmail.com. Mobile: +628525731170o. 